\title{
ФОРМУВАННЯ СИНДРОМУ ПРОФЕСІЙНОГО ВИГОРАННЯ У СПІВРОБІТНИКІВ ВІДДІЛЕННЯ АНЕСТЕЗІОЛОГІЇ ТА ІНТЕНСИВНОЇ ТЕРАПІЇ
}

\author{
М.-В. А. Штинь ${ }^{1}$, I. М. Маланчин ${ }^{2}$ \\ ${ }^{1}$ КНП «Обласна клінічна лікарня Івано-Франківської обласної ради» \\ ${ }^{2}$ Тернопільський національний медичний університет \\ імені І. Я. Горбачевського МОЗ Украӥни
}

У статті проаналізовано результати обстежень медичних працівників відділення анестезіології та інтенсивної терапії щодо виникнення синдрому емоційного вигорання. Встановлено, що рівень вираження цього синдрому найвищий серед середнього медичного персоналу відділення анестезіології та інтенсивної терапії, однаковий у вікових групах 20-29 та 30-39 років серед осіб жіночої статі.

\section{PROFESIONAL BURNOUT SYNDROME FORMATION AMONG MEDICAL PERSONNEL OF ANESTHESIOLOGY AND INTENSIVE THERAPY DEPARTMENT}

\author{
M.-V. A. Shtyn ${ }^{1}$, I. M. Malanchyn ${ }^{2}$ \\ ${ }^{1}$ Communal Noncommercial Enterprise "Regional Clinical Hospital of \\ Ivano-Frankivsk Regional Council” \\ ${ }^{2}$ I. Horbachevsky Ternopil National Medical University
}

The article analyzes the results of the occurrence of emotional burnout syndrome among medical personnel of the anesthesiology and intensive therapy department. It was found that the level of expression of this syndrome was highest among nurses of the department, equally in the age groups 20-29 and 30-39 years, among women.

Вступ. На сьогодні синдром емоційного вигорання (CEB) перетворився на «хворобу» соціальних і комунікативних професій. При цьому значно розширився перелік самих професій, а також кількість симптомів, які зумовлюють цю патологію. Специфіка роботи медичних працівників характеризується тим, що в них наявна значна кількість ситуацій з високою емоційною насиченістю і когнітивною складністю міжособистісного спілкування. Це вимагає від фахівця значного внеску до встановлення довірливих стосунків і вміння управляти емоційним напруженням ділового спілкування [1-3]. Проблема синдрому емоційного вигорання та професійної дезадаптації набуває особливої актуальності у роботі медичного персоналу відділень анестезіології, інтенсивної терапії та реанімації. Ще не до кінця з'ясовано та виділено єдині діагностичні критерії, тому в деяких випадках синдром складно вчасно діагностувати, а також розробити профілактичні та реабілітаційні програми $[3,4]$. Метою дослідження

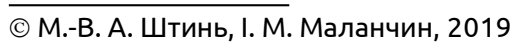

$\epsilon$ вивчення особливостей синдрому професійного вигорання у співробітників відділення анестезіології та інтенсивної терапії (BAIT) КНП «Обласна клінічна лікарня Івано-Франківської обласної ради».

Основна частина. Для реалізації поставленої мети обстежено 65 медичних працівників відділення анестезіології та інтенсивної терапії. Серед них було 53 (81,5 \%) жінки та 12 (18,5\%) чоловіків. Серед обстежених співробітників було 8 (12,3\%) молодших медичних сестер, 36 (55,4 \%) медичних сестер, 21 (32,3\%) лікар. За віком респондентів поділили таким чином: 20-29 років - 12 (18,5\%), 30-39 років - 21 (32,3\%), 40-49 років - 12 (18,5\%), 50-59 років - 12 (18,5\%), 60 та більше років - 8 (12,2\%). Стаж роботи 0-9 років мали 19 (29,2 \%) співробітників, 10-19 років - 19 (29,2 \%) осіб, 20-29 років - 12 (18,5 \%), 30-40 років - 15 (23,1\%).

Для діагностики рівня емоційного вигорання застосовували опитувальник «Визначення психічного «вигорання» О. О. Рукавішнікова. Респондентам пропонували відповісти на низку запитань-тверджень 
щодо відчуттів, пов'язаних із роботою. Опитувальник містить 72 запитання, чотири варіанти відповідей «ніколи», «зазвичай», «рідко» та «часто». Співробітникам рекомендували відповідати якомога швидше на запитання, довго не міркувати над вибором відповіді. Ця методика має три шкали: психоемоційного виснаження (ПВ), особистісного віддалення (ОВ) і професійної мотивації (ПМ) [5]. Для визначення психічного «вигорання» в межах вказаних шкал використовують спеціальний ключ. Психоемоційне виснаження - процес вичерпання емоційних, фізичних, енергетичних ресурсів професіонала, який працює з людьми. Виснаження проявляється у хронічній емоційній і фізичній втомі, байдужому та холодному ставленні до людей з ознаками депресії та роздратованості. Для визначення ПВ використовують 25 тверджень із опитувальника. Особистісне віддалення - специфічна форма соціальної дезадаптації професіонала, який працює з людьми. Особистісне віддалення характеризується зменшенням кількості контактів з оточенням, підвищенням роздратованості та нетерплячості в ситуаціях спілкування, негативізмом стосовно до інших. Для визначення ОВ застосовують 24 твердження з анкети. Професійна мотивація - рівень робочої мотивації і ентузіазму щодо роботи альтруїстичного змісту. Стан емоційної сфери оцінюють таким показником, як продуктивність професійної діяльності, оптимізм та зацікавленість у роботі, самооцінка професійної діяльності та ступеня успішності в роботі з людьми. Для оцінки ПМ застосовують 23 твердження з опитувальника. Для всіх трьох компонентів існують свої норми. Тест передбачає п'ять рівнів сформованості: «вкрай високий», «високий», «середній», «низький»і «вкрай низький».

Аналізуючи результати компонента «психоемоційне виснаження» серед різних професійних груп відділення анестезіології та інтенсивної терапії, виявлено, що вкрай високі значення були в 7 (10,8 \%) працівників. У цій підгрупі переважали медичні сестри - 5 (7,7\%) осіб. Високий рівень сформованості ПВ мав місце у 11 (16,9 \%) медичних сестер, 5 (7,7\%) лікарів і однієї (1,6 \%) молодшої медичної сестри. Вкрай низькі значення були в 2 (3,1%) лікарів, однієї медичної сестри та однієї санітарки (1,6 \%).

Серед обстежених працівників відділення вкрай низькі значення компонента «особистісне віддалення» виявлено в 3 (4,6 \%) лікарів та у 2 осіб серед середнього та молодшого медичного персоналу. Вкрай високі показники ОВ мали також 3 (4,6 \%) лікарі,
2 (3,1 \%) медичні сестри і одна молодша медична сестра. Високі значення компонента ОВ мали 15 (23,1 \%) працівників BAIT, серед яких переважав середній медичний персонал - 11 (16,9\%).

Високі значення компонента «професійна мотивація» були в 6 (9,3 \%) лікарів, 13 (20\%) медичних сестер та однієї (1,5 \%) молодшої медичної сестри. Вкрай високі показники ПМ переважали у лікарів - 3 (4,6 \%). Вкрай низькі показники даного компонента мали місце у однієї молодшої медичної сестри.

Високі та вкрай високі показники компонента «психоемоційне виснаження» переважали у жінок, відповідно, в 22 (33,8 \%) респонденток проти 2 (3,1 \%) чоловіків. Вкрай низькі та низькі значення були в 10 (15,4 \%) жінок та 5 (7,7 \%) чоловіків. Середні показники цього компонента переважали у співробітників жіночої статі - 21 (32,3 \%) особа.

Аналізуючи результати опитування щодо компонента «особистісне віддалення», можна констатувати, що тут переважали середні показники серед співробітниць. Цей результат мав місце в 27 (41,5\%) працівників відділення, серед яких 23 (35,4 \%) жінки. Низькі та вкрай низькі значення компонента виявили у 12 (18,5\%) медичних працівниць і 5 (7,7\%) чоловіків. Вкрай високі та високі показники показали 18 (27,7\%) опитуваних респонденток і лише 3 респондентів.

Високі та вкрай високі значення компонента «професійна мотивація» мали місце в 26 (40\%) жінок і 3 (4,6 \%) чоловіків. Вкрай низькі та низькі показники були в 4 працівниць і одного співробітника.

Вивчаючи особливості формування синдрому професійного вигорання у медичного персоналу ВАІT, ми вирішили проаналізувати показники всіх компонентів залежно від віку респондентів. Вкрай високе значення компонента ПВ мали співробітники віком 20-29 років (4,6 \%), 40-49 років (3,1\%), а також 50-59 років (3,1 \%). Серед вікової групи 30-39, 60 і більше років таких осіб не було. Високі показники компонента «психоемоційне виснаження» виявлено у всіх вікових групах. Вони були однакові та переважали у групах працівників 20-29, 30-39 років, відповідно, по 9,2 \%. Вкрай низькі та низькі значення мали респонденти 40-60 та більше років.

Вкрай низькі значення компонента ОВ мали по 2 особи у кожній з перерахованих вікових груп: 30-39, 50-59, 60 і більше років. Вкрай високі показники ОВ переважали у співробітників віком 30-39 років (2 особи), а також 50-59 років (3 особи). Високі значення цього компонента були у всіх вікових групах, але 
найчастіше спостерігали у молодих працівників віком 20-29 років. Таких співробітників було 5 (7,7 \%).

Серед показників компонента ПМ переважали середні значення, вони мали місце у 27 (41,5 \%) працівників різного віку. Найбільше респондентів було серед вікової групи 30-39 років - 11 (16,9 \%) осіб. Вкрай низький показник зафіксовано лише в одного співробітника віком 60 років. Високі значення були в 20 працівників, найбільше серед осіб віком 30-39 років (10,8 \%), 40-49 років (7,7\%), 20-29 років (6,2 \%). Вкрай високі показники ПМ мали місце в 8 (12,3 \%) співробітників. У цій групі найбільше було респондентів віком 20-29 та 30-39 років, по 3 особи відповідно.

За результатами дослідження встановлено, що у співробітників відділення анестезіології та інтенсив-

\section{СПИСОК ЛІТЕРАТУРИ}

1. Аймедов К. В. Синдром емоційного вигорання у лікарів-хірургів в залежності від професійного стажу / К. В. Аймедов // Психічне здоров'я. - 2015. - № 1 (46). - С. 7-9.

2. Шатило В. Й. Синдром емоційного вигорання в професії медичної сестри / В. Й. Шатило, А. А. Мельник // Головна медична сестра : спеціалізоване видання для головних медичних сестер. - 2012. - № 12. - С. 41.

3. Action collaborative on clinician well-being and resilience [Electronic resource] / National Academy of Medicine. - ної терапії є ознаки синдрому емоційного вигорання. Визначені особливості проявів цього синдрому в медичних працівників дають зрозуміти механізм їх негативного впливу на якість надання медичної допомоги в лікувальному закладі. Необхідно проводити корекцію синдрому вигорання з урахуванням індивідуальних особливостей його прояву.

Висновки. Встановлено, що рівень вираження синдрому вигорання найвищий серед середнього медичного персоналу BAIT, однаковий у вікових групах 20-29 та 30-39 років серед осіб жіночої статі. Цей синдром необхідно вчасно ідентифікувати, аналізувати, оскільки він має негативний вплив на якість надання медичної допомоги у медичних закладах.

2017. - Access mode : http:// nam. edu / initiatives / clinician- resilience-and-well-being.

4. Papovic S. Professional burnout syndrome / S. Papovi // Materia Socio Medica. - 2019. - Vol. 21, No. 4. - P. 213-215.

5. Фетискин Н. П. Социально-психологическая диагностика развития личности и малых групп / Н. П. Фетискин, В. В. Козлов, Г. М. Мануйлов. - М. : Изд-во Института психотерапии, 2002. - С. 357-360. 